\title{
Effectiveness of Computer Assisted Teaching Program on Knowledge and Attitude Regarding Smartphone Separation Anxiety among Students
}

\section{Poonam Kumari Yadav ${ }^{1 *}$, Anil Kumar Yadav², Avinash Chaudhary ${ }^{3}$ and Pankaj Shah ${ }^{4}$}

${ }^{1}$ Nursing Instructor, Birgunj Nursing Campus, Birgunj, Parsa, Nepal

${ }^{2}$ MDS, Department, Orthodontics and Dentofacial Orthopedics Unit, Department of

Dentistry, Tribhuvan University Teaching Hospital, Kathmandu, Nepal

${ }^{3}$ Senior Resident, Department of Orthodontics, College of Dental surgery, B.P. Koirala

Institute of Health Sciences, Dharan, Nepal

${ }^{4}$ Post Graduate Resident, Department of Prosthodontics and Crown-Bridge, College

of Dental Surgery, B.P. Koirala Institute of Health Sciences, Dharan, Nepal

*Corresponding Author: Poonam Kumari Yadav, Nursing Instructor, Birgunj

Nursing Campus, Birgunj, Parsa, Nepal.
Received: October 17, 2020

Published: November 30, 2020

(C) All rights are reserved by Poonam Kumari

Yadav., et al.

\begin{abstract}
Objective: The objective of this study was to assess the effectiveness of computer assisted teaching program on knowledge and attitude regarding smartphone separation anxiety among selected degree college students.

Methodology: A pre-experimental one group pre-test and post-test design was used. 50 degree students were selected as sample by convenient sampling method. Structured knowledge questionnaire was used to assess the knowledge and attitude on Likert scale. Pre-tested semi-structured questionnaire was used to collect data on socio-demographic characteristics. Paired t-test was used to test difference in mean knowledge and attitude. Chi-square test was used to find association between socio-demographic variables with pre-test knowledge and attitude.

Results: The overall mean score knowledge in pre-test was $37.42 \%$ and $86.11 \%$ in the post-test. The overall attitude mean score in pre-test was $42.55 \%$ and $82.81 \%$ in the post-test. Mean score for both knowledge and attitude were significant at $5 \%$ level of confidence. There was no significant association with the pre-test knowledge and attitude scores with selected demographic variable. Conclusion: This study suggested that computer assisted teaching program is an effective instructional method in improving the knowledge and attitude of degree students regarding smartphone separation anxiety.
\end{abstract}

Keywords: Computer Assisted Teaching; Knowledge and Attitude; Separation Anxiety

\section{Introduction}

Mobile phones have become an essential part of modern human life. New research has shown excessive use of mobile phones leading to development of symptoms suggestive of dependence syndrome [1]. If a child or teenager suffers a cell phone addiction, it could have negative implications on brain development [2]. David Greenfield supported the theory that attachment to a smart phone is similar to other addictions as it interferes with the production of dopamine, which is the hormone of 'happiness'. This theory proposes that notifications for messages and emails, and the sound of the phone ring often trigger dopamine which slightly increase, as people assume that it may be a text message from someone they like, an email with good news, an invitation to a party/event or something exciting [3]. 
The term Nomophobia was first coined by British researchers in 2008. A study conducted in Philadelphia found that $66 \%$ of people fear of being without a mobile phone, 18 - 24 age group ranks first in nomophobia [1]. A study showed that people on an average check their mobile phones 34 times a day, and $77 \%$ unable to stay apart for more than a few minutes [4]. With so many utility applications being made available on mobile phones, be it to surf the internet or to pay bills, this dependency on mobile phones is escalating at a greater pace [5]. Research has revealed $92 \%$ of teens say that they go online daily, while $24 \%$ to be online "almost constantly." $94 \%$ of teenagers access the Internet via their smart phones at least once a day, if not more. Facebook is the most-commonly visited social media site for teens (71\%), followed by Instagram (52\%), then Snapchat (44\%) [6]. In fact, college students are regarded as the early adopters of smartphones [6].

A cross sectional study results revealed that overall $18.5 \%$ (19\% male and 18\% female) students were found to be nomophobic. Moreover 20\% students responded that they lose their concentration and become stressed when they do not have their mobile phones with them [7]. Teenagers are suffering from an addiction to Smartphone with signs and symptoms like anxiety, depression, change in sleep patterns, fatigue, depressed or irritable mood, little interest in activities, difficulties paying attention, withdrawal from social interaction or activities, low self-esteem, neglecting other activities and, sore neck or headaches. Experiencing "phantom vibration syndrome", which means checking his or her phone when it hasn't vibrated or rungt [8]. Study revealed that the Smartphone Addiction Scale scores of females were significantly higher than those of males. Depression, anxiety, and daytime dysfunction scores were higher in the high smart phone use group than in the low smart phone use group. Positive correlations were found between the Smartphone Addiction Scale scores and depression levels, anxiety levels, and some sleep quality scores [8,9]. In a descriptive study by Szpakow., et al. showed that only $28.8 \%$ had knowledge about Smartphone separation anxiety (nomophobia) and $10.4 \%$ of the students had the symptoms of addiction. Smartphone separation anxiety is new to the people and many of them are not aware of the problem. The degree students are more affected with Smartphone separation anxiety because the youth always keep them updated with the technology and more fond of them.

\section{Aim of the Study}

This study aimed to assess the effectiveness of Computer assisted teaching program on knowledge and attitude regarding Smartphone separation anxiety among degree students.

\section{Materials and Methods}

The pre-experimental design was used in the study i.e. one group pre-test post-test design. Convenience sampling technique was used. 50 degree students (20 male and 30 female) of Visweshwarapuram College of science participated in the study. Inclusion criteria were degree students between 18-30 years of age who were willing to participate in the study. The exclusion criteria were degree students suffering from any illness and who have already attended education program on smartphone separation anxiety. The structured questions were validated by a group of experts consisting of one consultant Psychiatrist and five faculties from Psychiatric nursing fields. Validity of the tool was assessed by administration on 10 degree students. Structured questions consisted of 38 questions with one right answer. The score for correct response was one and zero for incorrect. The computer assisted teaching program was developed and validated. A pilot study was conducted at Vasavi Vidyanikethan College, Bangalore to find stability of study. Permission from Principal of degree college Visweshwarapuram College of science was obtained. On day 1 structured questionnaire on knowledge and attitude on smart phone separation anxiety was assessed on Likert scale. The time taken for pre-test was 40-45 minutes. The computer assisted teaching program was administered on day 1 which took 40 minutes. On the $8^{\text {th }}$ day after the administration of Computer assisted teaching program the post test was conducted by the investigator using the same questionnaire and scale at the same place.

\section{Statistical analysis}

Frequency and percentage distribution was used for analysis of socio-demographic characteristics. Mean, standard deviation of pre-test and post-test scores were calculated. Paired ' $t$ ' test was used to ascertain whether there is significant difference in the mean knowledge and attitude score of pre-test and post-test values. Chi-square test was used to find the association between socio-demographic variables with pre-test knowledge and attitude scores. 


\begin{tabular}{|c|c|c|c|c|}
\hline \multirow{2}{*}{ Knowledge Level } & \multicolumn{4}{|c|}{ Classification of Respondents } \\
\cline { 2 - 5 } & \multicolumn{2}{|c|}{ Pre test } & \multicolumn{2}{c|}{ Post test } \\
\cline { 2 - 5 } & Number & Percent & Number & Percent \\
\hline Inadequate (<50\%) & 44 & 88 & 00 & 00 \\
\hline Moderate (50-75\%) & 6 & 12 & 05 & 10 \\
\hline Adequate (>75\%) & 00 & 00 & 45 & 90 \\
\hline Total & 50 & 100.0 & 50 & 100 \\
\hline
\end{tabular}

Table 1: Classification of respondents on knowledge scores regarding smartphone separation anxiety.

\begin{tabular}{|c|c|c|c|}
\hline \multirow{2}{*}{$\begin{array}{l}\text { Demographic } \\
\text { Variables }\end{array}$} & \multirow{2}{*}{ Category } & \multicolumn{2}{|c|}{ Respondents } \\
\hline & & Frequency & Percent \\
\hline \multirow{2}{*}{ Age } & 19 - 20 Years & 32 & 64 \\
\hline & 21 - 22 Years & 18 & 36 \\
\hline \multirow{2}{*}{ Sex } & Male & 20 & 40 \\
\hline & Female & 30 & 60 \\
\hline \multirow{3}{*}{ Religion } & Hindu & 35 & 70 \\
\hline & Muslim & 10 & 20 \\
\hline & Christian & 5 & 10 \\
\hline \multirow{2}{*}{ Family } & Nuclear & 38 & 76 \\
\hline & Joint & 12 & 24 \\
\hline \multirow{3}{*}{ Year of Study } & First Year & 20 & 40 \\
\hline & Second Year & 18 & 36 \\
\hline & Third Year & 12 & 24 \\
\hline \multirow{2}{*}{$\begin{array}{l}\text { Monthly family } \\
\text { income }\end{array}$} & Upto 15000 & 25 & 50 \\
\hline & $>15000$ & 25 & 50 \\
\hline \multirow{3}{*}{$\begin{array}{l}\text { Years of use of } \\
\text { Smartphones }\end{array}$} & Upto 2 Years & 5 & 10 \\
\hline & 2 to 5 Years & 38 & 76 \\
\hline & $>5$ Years & 7 & 14 \\
\hline \multirow{3}{*}{$\begin{array}{c}\text { Hours of use of } \\
\text { Smartphones per day }\end{array}$} & Upto 3 hours & 10 & 20 \\
\hline & 3-6 hours & 28 & 56 \\
\hline & $>6$ hours & 12 & 24 \\
\hline
\end{tabular}

Table 2: Demographic variable of respondents.

\section{Results}

The reliability of the tool was found out to be 0.902 for knowledge and 0.85 for attitude on Pearson's co-efficient which indicates that the tool is reliable. The overall mean score in the pre-test for

\begin{tabular}{|c|c|c|c|c|}
\hline \multirow{2}{*}{ Attitude Level } & \multicolumn{3}{|c|}{ Classification of Respondents } \\
\cline { 2 - 5 } & \multicolumn{2}{|c|}{ Pre test } & \multicolumn{2}{c|}{ Post test } \\
\cline { 2 - 5 } & Number & Percent & Number & Percent \\
\hline Unfavorable ( 5 40\%) & 35 & 70 & 00 & 00 \\
\hline Neutral (41- 60\%) & 15 & 30 & 20 & 40 \\
\hline Favorable (> 60\%) & 00 & 00 & 30 & 60 \\
\hline Total & 50 & 100 & 50 & 100.0 \\
\hline
\end{tabular}

Table 3: Classification of respondents on attitude scores regarding smartphone separation anxiety.

\begin{tabular}{|c|c|c|c|c|c|c|c|c|}
\hline \multirow[b]{2}{*}{$\begin{array}{l}\text { Aspects of } \\
\text { knowledge }\end{array}$} & \multicolumn{2}{|c|}{ Pre test } & \multicolumn{2}{|c|}{ Post test } & \multirow{2}{*}{$\begin{array}{l}\text { Mean } \\
\% \\
\text { differ- } \\
\text { ence }\end{array}$} & \multirow[b]{2}{*}{$\begin{array}{c}\mathbf{t} \\
\text { value }\end{array}$} & \multirow[b]{2}{*}{ DF } & \multirow[b]{2}{*}{$\begin{array}{c}P \\
\text { value }\end{array}$} \\
\hline & $\begin{array}{c}\text { Mean } \\
\%\end{array}$ & SD & $\begin{array}{c}\text { Mean } \\
\%\end{array}$ & SD & & & & \\
\hline \begin{tabular}{|c|} 
Concept of \\
Smart Phone \\
Separation \\
Anxiety
\end{tabular} & 35.67 & 0.88 & 83.67 & 0.68 & 48 & 16.430 & 49 & $\begin{array}{c}\mathrm{P}< \\
0.05^{*}\end{array}$ \\
\hline $\begin{array}{r}\text { Causes } \\
\text { Stag }\end{array}$ & 41.00 & 0.67 & 84.00 & 0.70 & 43 & 21.843 & 49 & $\begin{array}{c}\mathrm{P}< \\
0.05^{*}\end{array}$ \\
\hline $\begin{array}{l}\text { Signs and } \\
\text { symptoms }\end{array}$ & 41.75 & 1.15 & 88.50 & 0.83 & 46.75 & 21.575 & 49 & $\begin{array}{c}\mathrm{P}< \\
0.05^{*}\end{array}$ \\
\hline $\begin{array}{l}\text { Manage- } \\
\text { ment and } \\
\text { prevention }\end{array}$ & 34.89 & 2.10 & 86.56 & 1.63 & 51.67 & 23.415 & 49 & $\begin{array}{c}\mathrm{P}< \\
0.05^{*}\end{array}$ \\
\hline $\begin{array}{c}\text { Overall } \\
\text { knowledge }\end{array}$ & 37.42 & 3.23 & 86.11 & 2.44 & 48.69 & 32.693 & 49 & $\begin{array}{c}\mathrm{P}< \\
0.05^{*}\end{array}$ \\
\hline \multicolumn{9}{|c|}{ *is significant; $\mathrm{t}(0.05,49 \mathrm{df})=2.0096$} \\
\hline
\end{tabular}

Table 4: Comparison of pre-test and post-test of knowledge score regarding smartphone separation anxiety.

knowledge was $37.42 \%$ and $86.11 \%$ in the post-test with a difference of $48.69 \%$ with paired " $t$ " test value of 32.693 which is significant at 0.05 level. There was significant difference found between the pre-test and post-test knowledge scores regarding Smart Phone Separation Anxiety. There exist a significant poor positive correlation between knowledge and attitude of respondents on smartphone separation anxiety. There is no significant association with the pre-test knowledge scores with selected demographic variable. There is no significant association with the pre-test attitude level with selected demographic variables. 
Effectiveness of Computer Assisted Teaching Program on Knowledge and Attitude Regarding Smartphone Separation Anxiety among Students

192

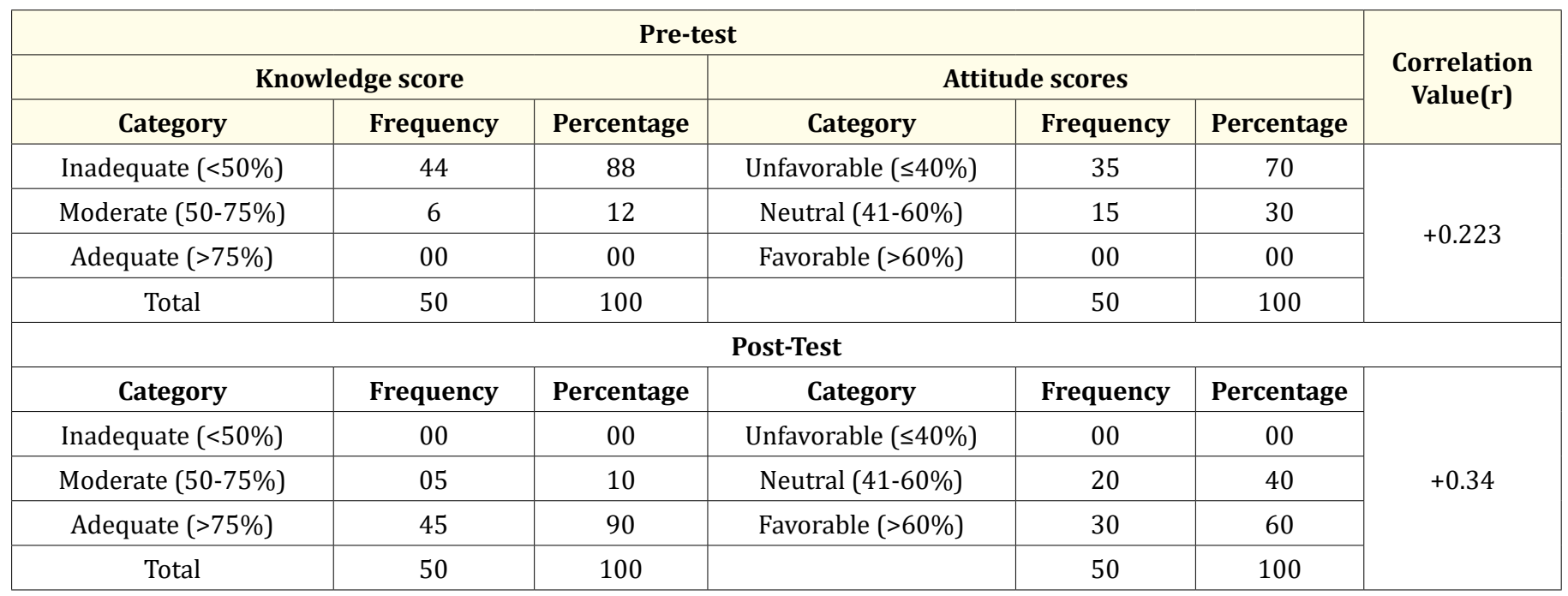

Table 5: Correlation between knowledge and attitude scores.

\section{Discussion}

Pre-experimental one group pre-test and post-test design was used to conduct the study. Research approach was an evaluative approach. The target population for the study was degree students studying at selected College, Bengaluru. Gender wise distribution of the respondents revealed that majority $30(60 \%)$ respondents were female and remaining $20(40 \%)$ respondents were male. Majority $20(40 \%)$ respondents are First year students, 36\% of respondents are Second year students and 24\% respondents are Third year students. Majority 38 (76\%) respondents are using mobile phone for duration of 2 to 5 years, 7 (14\%) respondents are using mobile phone for duration more than 5 years, and 5 (10\%) respondents are using mobile phone for duration less than 2 years. Average time of smart phone use per day revealed that majority 28 (56\%) respondents use between 3-6 hours, 24\% respondents Average time of smart phone use per day is more than 6 hours, and remaining 20\% respondents Average time of smart phone use per day is less than 3 hours. The highest pre-test mean attitude score $(43.32 \%)$ was obtained in the aspect of positive statements and $41.76 \%$ in negative statements. However, the overall pre-test mean attitude score was found to be $42.55 \%$. The Pre-test attitude level shows that 35 (70\%) of the respondents had unfavorable attitude and $15(30 \%)$ of the respondents had neutral attitude. The highest
(85.66\%) post-test mean attitude score was obtained in the aspect of positive statements and $79.96 \%$ in negative statements. However, the overall post-test mean attitude score was fond to be $82.81 \%$.

The Post-test attitude level shows that $45(70 \%)$ of the respondents had favorable attitude and 5 (10\%) of the respondents had neutral attitude A similar study was conducted on Problematic Mobile phone use among Adolescent, Iran. The study results show Most of the participants were females (62.7\%), aged between 22 $29 y e a r s$ (38.5\%), Nuclear family (59.2\%), and used mobile phone between 4-6 hours per day (86.9\%) [11]. Findings of the Pre-test showed that highest mean percentage was seen in the aspect of signs and symptom is $41.75 \%$ followed by causes and stages is $41.00 \%$; Concept of Smart phone Separation anxiety is $35.67 \%$. Lowest mean percentage was seen in knowledge about management and prevention is $34.89 \%$. The overall knowledge of pre-test mean percentage is 37.42 . The Pre-test knowledge level shows that $44(88 \%)$ of the respondents had inadequate knowledge and $6(12 \%)$ of the respondents had moderate knowledge. The finding of the Present study is contrary to an across-sectional study conducted to investigate knowledge, perception of students, Africa. The study results established $68.52 \%$ of the factors related to mobile phone addiction were known by at least $81.54 \%$ of the students [12]. The highest mean post-test knowledge percentage 
was seen in the aspect of signs and symptoms is $88.50 \%$ followed by management and prevention is $86.56 \%$, and causes and stages is $84.00 \%$ and lowest post-test mean knowledge percentage was seen in knowledge about concept of Smart Phone Separation Anxiety is $83.67 \%$. The overall knowledge of post-test mean percentage is $86.11 \%$. The Post-test knowledge level shows $60 \%$ of the respondents had adequate knowledge and $40 \%$ of the respondents had moderate knowledge regarding smart phone separation anxiety. The highest mean post-test knowledge percentage was seen in the aspect of signs and symptoms is $88.50 \%$ followed by management and prevention is $86.56 \%$, and causes and stages is $84.00 \%$ and lowest post-test mean knowledge percentage was seen in knowledge about concept of Smart Phone Separation Anxiety is $83.67 \%$.

The overall knowledge of post-test mean percentage is $86.11 \%$. The Post-test knowledge level shows $60 \%$ of the respondents had adequate knowledge and $40 \%$ of the respondents had moderate knowledge regarding smart phone separation anxiety.

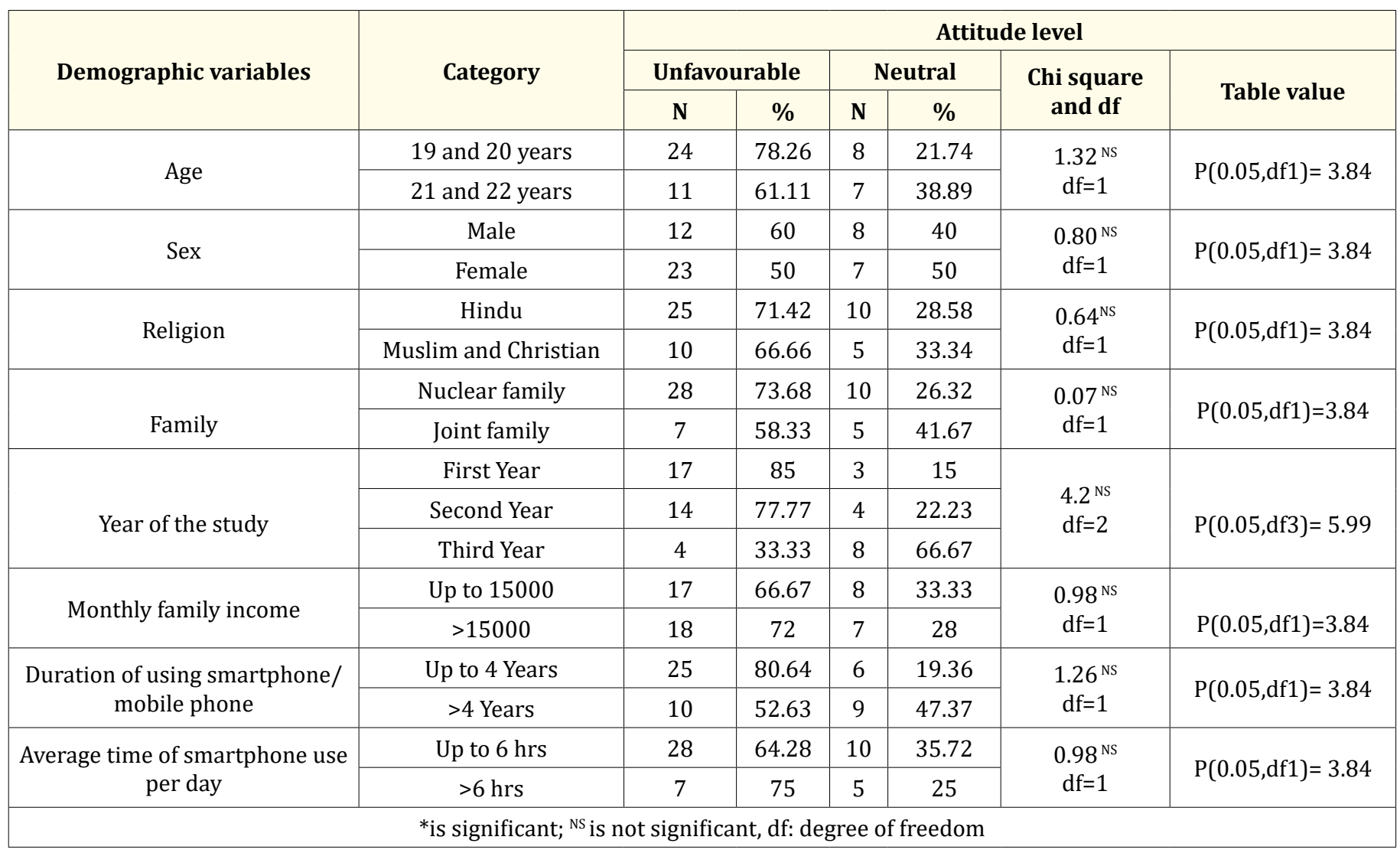

Table 6: Association between socio-demographic variables and pre-test attitude level on smartphone separation anxiety.

\section{Conclusion}

Respondents had inadequate knowledge regarding Smartphone separation anxiety. Conducting Computer assisted teaching program is to be effective in increasing knowledge of respondents.

\section{Declaration}

This study is part of my thesis during Master in Psychiatric Nursing. 


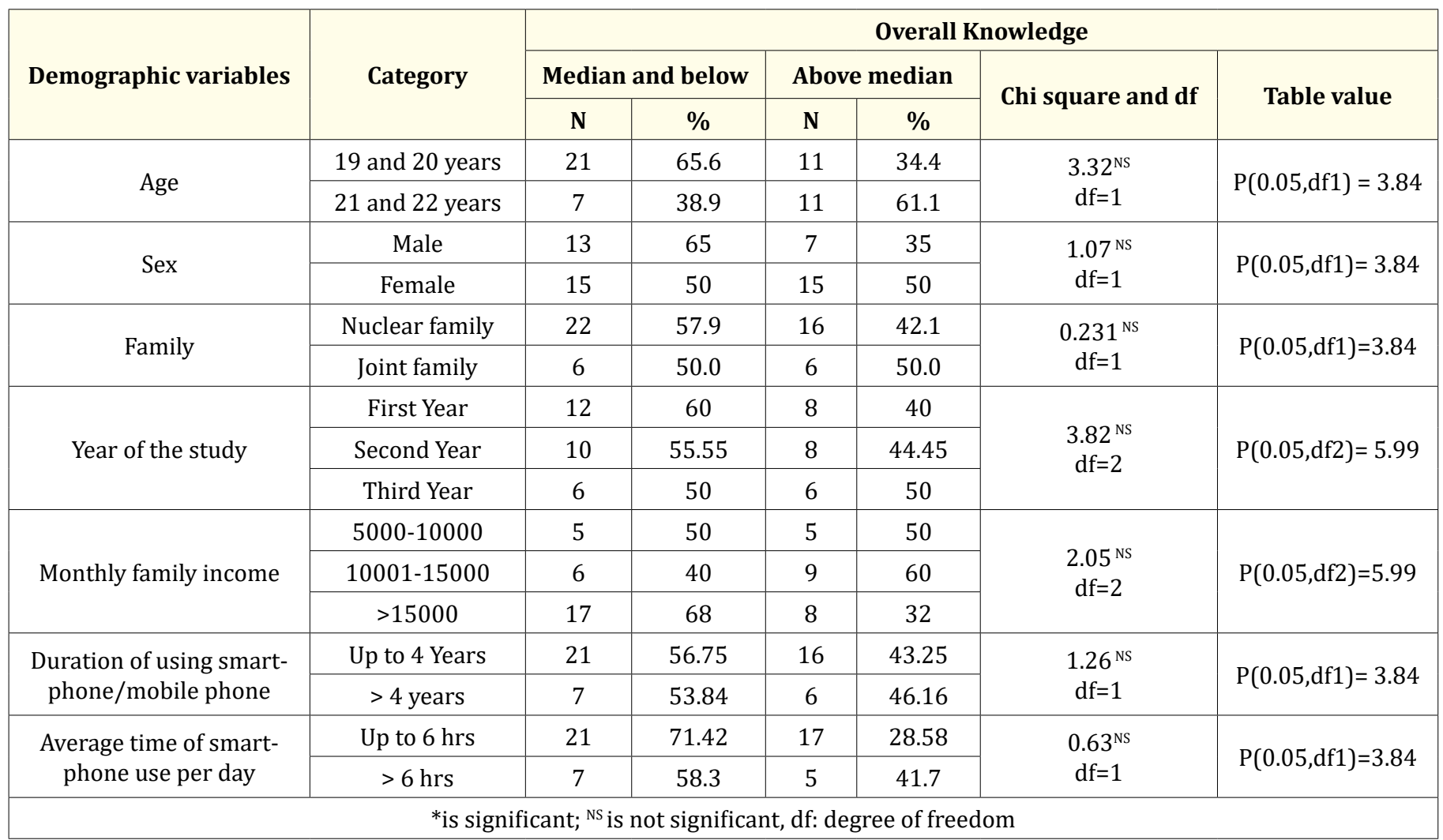

Table 7: Association between socio demographic variables and pre-test knowledge scores on smartphone separation anxiety.

\section{Bibliography}

1. Nikhita CS., et al. "Prevalence of Mobile Phone Dependence in Secondary School Adolescents". Journal of Clinical and Diagnostic Research: JCDR 9.11 (2015): VC06-VC09.

2. Teen Cell Phone Addiction.

3. Nomophobia and emotion.

4. Nomophobia: the fear of being without mobile affects 66 percent. The economic times (2012).

5. Singh DR and Goswami V. "Impact of mobile phone addiction on adolescent's life: A literature review". International Journal of Home Science 2.1 (2016): 69-74.

6. Social Media and Smartphone Addiction in Teens.
7. Cell phone ownership hits $91 \%$ of adults.

8. Kim Y., et al. "The effects of Internet addiction on the lifestyle and dietary behavior of Korean adolescents". Nutrition Research and Practice 4.1 (2010): 51.

9. Demirci K., et al. "Relationship of smartphone use severity with sleep quality, depression, and anxiety in university students". Journal of Behavioral Addictions 4.2 (2015): 85-92.

10. Szpakow A., et al. "Evaluation of threat of mobile phone - addition among Belarusian University students". Progress in Health Sciences 1.2 (2011): 96-101.

11. Shamali M., et al. "Problematic mobile phone use among adolescents". Journal of Public Health 4.3 (2015): e27766. 
12. Awa W., et al. "Knowledge and perception of students on Mobile phone addiction". Patient Education and Counseling 78.2

(2010): 184-190.

\section{Assets from publication with us}

- Prompt Acknowledgement after receiving the article

- Thorough Double blinded peer review

- Rapid Publication

- Issue of Publication Certificate

- High visibility of your Published work

Website: www.actascientific.com/

Submit Article: www.actascientific.com/submission.php

Email us: editor@actascientific.com

Contact us: +919182824667 